\title{
Fulvibacter tottoriensis gen. nov., sp. nov., a member of the family Flavobacteriaceae isolated from marine sediment
}

Correspondence

Shams Tabrez Khan

stkhan@nbrc.nite.go.jp

or

shamsalig75@gmail.com
Shams Tabrez Khan, Yasuyoshi Nakagawa and Shigeaki Harayama

Biological Resource Center (NBRC), National Institute of Technology and Evaluation (NITE), 2-5-8 Kazusakamatari, Kisarazu, Chiba 292-0818, Japan

\begin{abstract}
A novel bacterium, MTT-39 ${ }^{\top}$, was isolated from a sample of marine sediment collected at Tottori on the coast of the Sea of Japan. Cells were Gram-negative, rod-shaped and non-motile. The bacterium formed yellowish brown colonies on marine agar 2216. Although the 16S rRNA gene sequence of strain MTT-39 ${ }^{\top}$ classified this strain as a member of the family Flavobacteriaceae, the maximum sequence similarity obtained was only $91.5 \%$ (with Kordia algicida OT-1 ${ }^{\top}$ ). In the maximum-likelihood tree based on 16S rRNA gene sequences, the novel bacterium clustered with the type strains of Kordia algicida, Lutibacter litoralis, Tenacibaculum maritimum and Polaribacter filamentus. The novel strain exhibited the following characteristics: the predominant fatty acids in cells grown on artificial seawater-based tryptic soya agar were iso- $\mathrm{C}_{15: 1}$, iso- $\mathrm{C}_{15: 0}$ and iso$\mathrm{C}_{15: 0} 3-\mathrm{OH}$, the major respiratory quinone was MK-6 and the DNA G $+\mathrm{C}$ content was 35 mol\%. On the basis of its distinct phenotypic traits and the phylogenetic distance between this marine isolate and other recognized taxa, strain MTT- $39^{\top}$ represents a novel genus and species of the family Flavobacteriaceae, for which the name Fulvibacter tottoriensis gen. nov., sp. nov. is proposed. The type strain of the type species is MTT-39 ${ }^{\top}\left(=\right.$ NBRC $102624^{\top}=$ KCTC $22214^{\top}=$ CGMCC $1.7058^{\top}$ ).
\end{abstract}

Members of the phylum Bacteroidetes may constitute a large proportion of the bacterial community in marine environments, as detected by fluorescence in situ hybridization and analysis of 16S rRNA gene libraries (Glöckner et al., 1999; Alonso et al., 2007). Many Bacteroidetes strains belong to the family Flavobacteriaceae, in which they form a distinct 'marine clade' (Bowman, 2006). They are known for their capacity to degrade macromolecules such as proteins, chitin and other polysaccharides (Cottrell \& Kirchman, 2000) and thus may be important in carbon cycling in marine ecosystems. The family Flavobacteriaceae is rapidly expanding: 47 novel genera and many novel species have been described over the last five years, most of which are marine organisms (Bernardet \& Nakagawa, 2006).

The polyphasic characterization of a novel marine strain, MTT- $39^{\mathrm{T}}$, isolated from a sediment sample is described here. The sample was collected with a scoop, from a depth of 2$10 \mathrm{~cm}$, from the beach of Tottori $\left(134^{\circ} 5^{\prime} \mathrm{E} 35^{\circ} 31^{\prime} \mathrm{N}\right)$ in Japan. The strain was isolated using the dilution plating method on half-strength marine agar 2216 (HSMA; Difco). After 3-4 days incubation at $25{ }^{\circ} \mathrm{C}$, the colonies that formed

The GenBank/EMBL/DDBJ accession number for the 16S rRNA gene sequence of strain MTT-39 ${ }^{\top}$ is AB294107. were yellowish brown, smooth, circular with regular edges and $1-2 \mathrm{~mm}$ in diameter. Slants and plates of the same medium were used for routine cultivation at $25{ }^{\circ} \mathrm{C}$, while $20 \%(\mathrm{v} / \mathrm{v})$ glycerol in artificial seawater (ASW; Naigai Chemicals) was used for long-term preservation at $-80{ }^{\circ} \mathrm{C}$.

Isolation of DNA from strain MTT- $39^{\mathrm{T}}$, sequencing of the $16 \mathrm{~S}$ rRNA gene and phylogenetic analysis based on the $16 \mathrm{~S}$ rRNA gene sequence were performed as described previously (Khan et al., 2007). The results from the BLAST search suggested that strain MTT $-39^{\mathrm{T}}$ is a member of the family Flavobacteriaceae, sharing the highest $16 \mathrm{~S}$ rRNA gene sequence similarity (93\%) with an unpublished marine bacterium (GenBank accession no. EF100858). Pairwise sequence similarities between the 16S rRNA gene of strain MTT $-39^{\mathrm{T}}$ and those of recognized members of the family Flavobacteriaceae were also checked using the dynamic programming algorithm (Needleman \& Wunsch, 1970; http://www.ebi.ac.uk/emboss/align/). The highest sequence similarity was only $91.5 \%$, obtained with Kordia algicida OT- $1^{\mathrm{T}}$. In a phylogenetic tree based on $16 \mathrm{~S}$ rRNA gene sequences and constructed by using the maximum-likelihood method (Fig. 1), strain MTT-39 formed a stable cluster with $K$. algicida OT- $1^{\mathrm{T}}$, Lutibacter litoralis $\mathrm{CL}-\mathrm{TF} 09^{\mathrm{T}}$, Tenacibaculum maritimum ATCC 


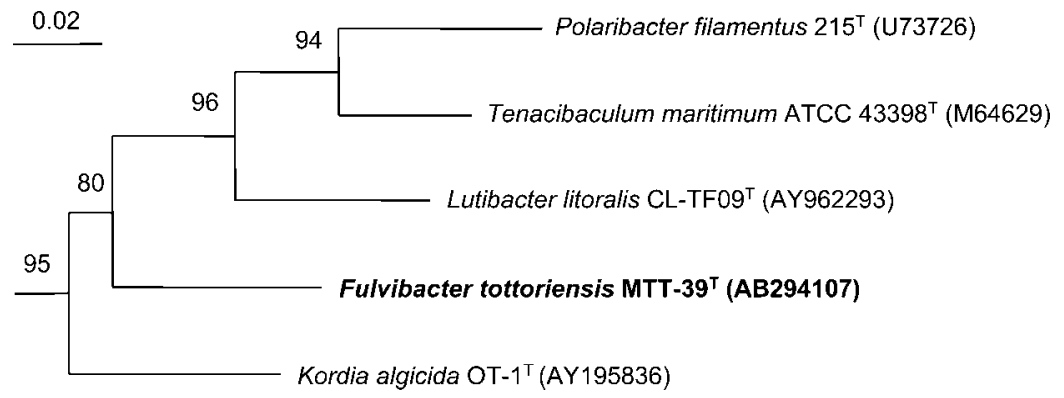

Fig. 1. Dendrogram inferred from maximumlikelihood analysis and based on almostcomplete 16S rRNA gene sequences of strain MTT-39 ${ }^{\top}$ and related members of the family Flavobacteriaceae. Numbers at nodes represent bootstrap percentages calculated from 100 resamplings. Flexibacter flexilis (GenBank accession no. AB078054) was used as an outgroup (not shown). Bar, 0.02 $K_{\text {nuc. }}$.

$43398^{\mathrm{T}}$ and Polaribacter filamentus $215^{\mathrm{T}}$. Similar results were obtained using a neighbour-joining analysis (data not shown).

Microscopic observations (Khan et al., 2007), Gramstaining (Cowan \& Steel, 1993; Buck, 1982) and gliding motility tests (Perry, 1973; Bernardet et al., 2002) were carried out as described previously. The absorption spectrum (260-700 nm) of an acetone extract of bacterial cells was obtained with a Shimadzu UV-visible spectrophotometer (UV-1650 PC) to assess the presence of carotenoid pigment(s). The bathochromic shift test with $20 \% \mathrm{KOH}(\mathrm{w} / \mathrm{v})$ was performed for the detection of flexirubin-type pigments (Fautz \& Reichenbach, 1980). Anaerobic growth was assessed on HSMA plates incubated in air-tight jars containing an AnaeroPack (Mitsubishi Gas Chemical Co.). Growth at 4, 10, 20, 25, 30, 35, 37, 40, 42 and $45{ }^{\circ} \mathrm{C}$ was assessed on HSMA plates. Salt tolerance was tested in marine broth 2216 (Difco) with final $\mathrm{NaCl}$ concentrations adjusted to $3,4,5,6,7,8,9$ and $10 \%(\mathrm{w} / \mathrm{v})$. Growth was also tested in 1/5-strength Luria-Bertani medium [2 g Bacto tryptone (Difco) and $1 \mathrm{~g}$ Bacto yeast extract (Difco) dissolved in a final volume of $1 \mathrm{l}$ ] prepared with $\operatorname{ASW}(0,30,50$ and $70 \%, v / v)$ and $\mathrm{NaCl}(0,1$ and $2 \%, \mathrm{w} / \mathrm{v})$. Growth requirements for divalent cations $\left(\mathrm{Mg}^{2+}\right.$ and $\left.\mathrm{Ca}^{2+}\right)$ were assessed in $1 / 5$-strength LuriaBertani medium with $2.8 \%(\mathrm{w} / \mathrm{v}) \mathrm{NaCl}$ and one of the following: $0.6 \%(\mathrm{w} / \mathrm{v})$ magnesium sulphate or $0.14 \%$ $(\mathrm{w} / \mathrm{v})$ calcium chloride. Utilization of different nitrogen sources [sodium nitrate $\left(7.8 \mathrm{~g} \mathrm{l}^{-1}\right)$, ammonium sulphate $\left(7.8 \mathrm{~g} \mathrm{l}^{-1}\right)$, sodium glutamate $\left(20 \mathrm{~g} \mathrm{l}^{-1}\right)$, Casamino acids $\left(10 \mathrm{~g} \mathrm{l}^{-1}\right)$ and peptone $\left.\left(10 \mathrm{~g} \mathrm{l}^{-1}\right)\right]$ was tested in medium SN (1.0 g glucose and $1.0 \mathrm{~g}$ Tris-base dissolved in $11 \mathrm{ASW}$, $\mathrm{pH}$ 7.0) to which $1 \mathrm{ml}$ filter-sterilized vitamin solution was added. The vitamin solution consisted of the following $\left(\mathrm{l}^{-1}\right.$ distilled water): $2.0 \mathrm{mg}$ biotin, $2.0 \mathrm{mg}$ folic acid, $10.0 \mathrm{mg}$ pyridoxine hydrochloride, $5.0 \mathrm{mg}$ thiamine hydrochloride, $5.0 \mathrm{mg}$ riboflavin, $5.0 \mathrm{mg}$ nicotinic acid, $5.0 \mathrm{mg}$ DLcalcium pantothenic acid, $0.1 \mathrm{mg}$ vitamin $\mathrm{B}_{12}, 5.0 \mathrm{mg}$ p-aminobenzoic acid and $5.0 \mathrm{mg}$ lipoic acid. Cells from a 2 day-old culture on HSMA were spotted onto a glass slide and flooded with $3 \%(\mathrm{v} / \mathrm{v})$ hydrogen peroxide to check for the presence of catalase. The presence of oxidase was tested by spotting a cell suspension (in sterile water) onto a cytochrome oxidase strip (Nissui Pharmaceuticals). Marine broth 2216 solidified with $1.5 \%$ (w/v) carrageenan (Type I; Sigma) or agar was used to test the ability of the strain to liquefy these compounds. The degradation of cellulose was assessed by immersing cellulose strips (No. 1 paper; Whatman) in a culture of strain MTT- $39^{\mathrm{T}}$ in $1 / 5$-strength LB medium prepared with ASW at $25{ }^{\circ} \mathrm{C}$ for 1 month. The degradation of carboxymethylcellulose was tested by observing the liquefaction of 1/5-strength LB medium solidified with $3 \%(\mathrm{w} / \mathrm{v})$ carboxymethylcellulose (High Viscosity; Sigma), while the degradation of casein, chitin, DNA, gelatin and starch was assessed using methods described in detail elsewhere (Cowan \& Steel, 1993; Lewin \& Lounsbery, 1969; Smibert \& Krieg, 1981). The novel isolate was tested using an API 20NE strip according to the instructions of the manufacturer (bioMérieux) except that inocula were prepared by suspending cells in sterile ASW. The GN2 MicroPlate system (Biolog) was used to test the utilization of 95 different carbon sources. The MicroPlate was inoculated by using the protocol of Rüger \& Krambeck (1994) before being incubated at $25{ }^{\circ} \mathrm{C}$ for 3 days. Acidification of the carbon sources included in the API $50 \mathrm{CH}$ strip was tested according to the manufacturer's instructions (bioMérieux), using inocula prepared in a mixture $(1: 1)$ of ASW and commercially available CHB medium (bioMérieux). Results were recorded after incubation of the two commercial systems for 3 days at $25{ }^{\circ} \mathrm{C}$. No utilization or acidification occurred for any of the carbon sources included in the Biolog GN2 microplate or the API $50 \mathrm{CH}$ strip, respectively. The poor growth of strain MTT$39^{\mathrm{T}}$ observed in these systems could be related to a requirement for cofactors. Therefore, the utilization of different carbon sources (adonitol, D-arabinose, D-galactose, D-glucose, D-mannose, glycerol, L-aspartic acid, Lglutamic acid, L-rhamnose, maltose, meso-erythritol, peptone, pyruvic acid, raffinose, sucrose, xylitol and yeast extract) was also tested using a basal medium containing either $1 \mathrm{ml}$ vitamin solution or $0.2 \mathrm{~g}$ each of peptone and yeast extract (Lewin \& Lounsbery, 1969) per litre ASW. The properties of strain MTT- $39^{\mathrm{T}}$ are given in the genus and species descriptions and in Table 1.

To compare the fatty acid content of strain MTT $-39^{\mathrm{T}}$ with those of its closest neighbours, $K$. algicida OT- $1^{\mathrm{T}}$ and $L$. litoralis CL-TF09 ${ }^{\mathrm{T}}$, the novel strain was grown for 3 days at $25{ }^{\circ} \mathrm{C}$ on the media that were used to grow these strains for 
Table 1. Characteristics that differentiate Fulvibacter gen. nov. from related genera

Genera: 1, Fulvibacter (this study); 2, Kordia (Sohn et al., 2004); 3, Lutibacter (Choi \& Cho, 2006); 4, Polaribacter (Gosink et al., 1998; Nedashkovskaya et al., 2005); 5, Tenacibaculum (Suzuki et al., 2001; Yoon et al., 2005, 2006; Choi et al., 2006; Jung et al., 2006; Sheu et al., 2007). +, Positive; -, negative; (+), weakly positive; Yв, yellowish brown; Y, yellow; v, variable; s/O, salmon or orange; NG, no growth; $\mathrm{NA}$, not available.

\begin{tabular}{|lccccc|}
\hline Characteristic & $\mathbf{1}$ & $\mathbf{2}$ & $\mathbf{3}$ & $\mathbf{4}$ & $\mathbf{5}$ \\
\hline Catalase/oxidase & $-/+$ & $-/+$ & $+/-$ & $\mathrm{V} / \mathrm{V}^{*}$ & $+/+^{*}$ \\
Colony colour & $\mathrm{YB}$ & $\mathrm{Y}$ & $\mathrm{Y}$ & $\mathrm{s} / \mathrm{O}$ & $\mathrm{Y}$ \\
Degradation of casein & + & + & $\mathrm{NA}$ & $+/ \mathrm{NG}$ & $+/ \mathrm{NA}$ \\
$\quad \begin{array}{l}\text {-Glucosidase } \\
\quad \text {-Galactosidase }\end{array}$ & + & - & + & $\mathrm{V}$ & $\mathrm{NA}$ \\
$\begin{array}{l}\text { Growth temperature } \\
\text { range }\left({ }^{\circ} \mathrm{C}\right)\end{array}$ & $10-37$ & $4-40$ & $5-30$ & $4-33$ & $4-41$ \\
Salinity range & $1-5$ & $1-5$ & $1-5$ & $1-6$ & $1-10$ \\
$\quad(\%$ NaCl, w/v) & & & & & \\
Nitrate reduction & - & + & - & $\mathrm{V}$ & $\mathrm{V}$ \\
$\begin{array}{l}\text { DNA G }+\mathrm{C} \text { content } \\
(\text { mol\%) }\end{array}$ & 35 & 34 & 34 & $30-33$ & $30-35$ \\
& & & & & \\
\hline
\end{tabular}

${ }^{\star}$ Data for some species are not available.

fatty acid analyses, i.e. tryptic soy agar (TSA) prepared with $75 \%(\mathrm{v} / \mathrm{v})$ ASW, and marine agar 2216 (Difco), respectively (Sohn et al., 2004; Choi \& Cho, 2006). Fatty acid analysis was performed by using the Sherlock Microbial Identification System (MIDI). Only slight differences were noticed between the fatty acid contents of strain MTT- $39^{\mathrm{T}}$ grown on the two different media: the presence of two minor fatty acids $\left(\mathrm{C}_{14: 0}\right.$ and $\left.\mathrm{C}_{16: 0}\right)$ and the proportions of iso- $\mathrm{C}_{15: 0}$ were medium-dependent (Table 2). The two profiles also differed significantly from those of $K$. algicida $\mathrm{OT}-1^{\mathrm{T}}$ and $L$. litoralis CL-TF $09^{\mathrm{T}}$. Respiratory quinones were analysed according to the protocol of Nakagawa \& Yamasato (1993). DNA was extracted from exponentially growing cells in marine broth $2216\left(\right.$ at $25{ }^{\circ} \mathrm{C}$ ) using the protocol of Minamisawa (1990). The HPLC method of Mesbah et al. (1989) was used to determine the G+C content of the extracted DNA.

Phylogenetic distances ( $\leqslant 91.5 \% 16 \mathrm{~S}$ rRNA gene sequence similarity) and differences in phenotypic characteristics (Tables 1 and 2) between strain MTT- $39^{\mathrm{T}}$ and related members of the family Flavobacteriaceae clearly indicated that this strain should be classified as a novel genus and species, for which the name Fulvibacter tottoriensis gen. nov., sp. nov. is proposed.

\section{Description of Fulvibacter gen. nov.}

Fulvibacter (Ful.vi.bac'ter. L. adj. fulvus yellowish brown; N.L. masc. n. bacter a rod; N.L. masc. n. Fulvibacter a rod that produces yellowish brown pigment).
Table 2. Fatty acid contents (\%) of strain $M T T-39^{\top}$ and related species

Strains: 1, MTT- $39^{\mathrm{T}}$ (MA; this study); $2, \mathrm{MTT}-39^{\mathrm{T}}$ (TSA in $75 \%$ ASW; this study); 3, K. algicida OT- ${ }^{\mathrm{T}}$ (TSA in $75 \%$ aged seawater; Sohn et al., 2004); 4, L. litoralis CL-TF09 ${ }^{\mathrm{T}}$ (MA; Choi \& Cho, 2006). The following fatty acids occur as traces (i.e $<1 \%$ ) in strain MTT$39^{\mathrm{T}}: \mathrm{C}_{10: 0}, \mathrm{C}_{11: 0}, \mathrm{C}_{12: 0}, \mathrm{C}_{13: 0}$, iso- $\mathrm{C}_{11: 0}$, iso- $\mathrm{C}_{12: 0}$, anteiso- $\mathrm{C}_{13: 0}$, iso$\mathrm{C}_{14: 0}, \mathrm{C}_{13: 1}, \mathrm{C}_{12: 0} 3-\mathrm{OH}$, iso- $\mathrm{C}_{13: 0} 3-\mathrm{OH}, \mathrm{C}_{14: 0} 2-\mathrm{OH}$, iso- $\mathrm{C}_{14: 0}$ 3-OH and iso- $\mathrm{C}_{16: 0} 3-\mathrm{OH}$. Collectively, these fatty acids represent $4-7 \%$ of the total fatty acid content.

\begin{tabular}{|c|c|c|c|c|}
\hline Fatty acid & 1 & 2 & 3 & 4 \\
\hline \multicolumn{5}{|c|}{ Straight-chain fatty acids } \\
\hline $\mathrm{C}_{14: 0}$ & & 2 & & \\
\hline $\mathrm{C}_{15: 0}$ & & & 1 & 2 \\
\hline $\mathrm{C}_{16: 0}$ & 1 & & & \\
\hline $\mathrm{C}_{18: 0}$ & & & & 1 \\
\hline \multicolumn{5}{|l|}{ Branched fatty acids } \\
\hline iso- $\mathrm{C}_{13: 0}$ & 2 & 3 & & \\
\hline anteiso- $\mathrm{C}_{13: 0}$ & & & & 1 \\
\hline iso- $\mathrm{C}_{14: 0}$ & & & & 2 \\
\hline iso- $\mathrm{C}_{15: 0}$ & 8 & 20 & 41 & 17 \\
\hline anteiso- $\mathrm{C}_{15: 0}$ & 2 & 3 & 3 & 15 \\
\hline \multicolumn{5}{|l|}{ Saturated fatty acids } \\
\hline $\mathrm{C}_{15: 1} \omega 6 c$ & & & & 2 \\
\hline iso- $\mathrm{C}_{15: 1}$ & 32 & 33 & & 4 \\
\hline anteiso- $\mathrm{C}_{15: 1}$ & 4 & 3 & & 2 \\
\hline iso- $\mathrm{C}_{16: 1} \mathrm{H}$ & & & & 1 \\
\hline $\mathrm{C}_{17: 1} \omega 6 c$ & & & & 1 \\
\hline iso- $C_{17: 1} \omega 9 c$ & & & 2 & \\
\hline \multicolumn{5}{|l|}{ Hydroxy fatty acids } \\
\hline $\mathrm{C}_{15: 0} 2-\mathrm{OH}$ & 2 & 1 & & 2 \\
\hline $\mathrm{C}_{15: 0} 3-\mathrm{OH}$ & 3 & 2 & 14 & 2 \\
\hline iso- $\mathrm{C}_{15: 0} 3-\mathrm{OH}$ & 7 & 11 & & 17 \\
\hline $\mathrm{C}_{16: 0} 3-\mathrm{OH}$ & 11 & 6 & 4 & \\
\hline iso- $\mathrm{C}_{16: 0} 3-\mathrm{OH}$ & & & & 13 \\
\hline $\mathrm{C}_{17: 0} 2-\mathrm{OH}$ & & & & 4 \\
\hline iso- $\mathrm{C}_{17: 0} 3-\mathrm{OH}$ & 7 & 5 & 22 & 4 \\
\hline \multicolumn{5}{|l|}{ Summed features* } \\
\hline 1 & & & & 1 \\
\hline 2 & 2 & 2 & & \\
\hline 3 & 6 & 4 & 3 & 1 \\
\hline Unknown fatty acid & & & 9 & \\
\hline
\end{tabular}

* Summed features are groups of two or three fatty acids that cannot be separated by GLC using the MIDI system. Summed feature 1 contains iso- $\mathrm{C}_{15: 1} \mathrm{I}$ and/or $\mathrm{C}_{13: 0} 3-\mathrm{OH}$, summed feature 2 contains $\mathrm{C}_{14: 0} 3-\mathrm{OH}$ and/or iso- $\mathrm{C}_{16: 1} \mathrm{I}$; summed feature 3 contains iso- $\mathrm{C}_{15: 0}$ 2- $\mathrm{OH}$ and/or $\mathrm{C}_{16: 1} \omega 7 c$.

Gram-negative, aerobic, non-motile, rod-shaped bacteria. Oxidase-positive and catalase-negative. Carotenoid-type pigments (absorption maxima at 425, 452 and $478 \mathrm{~nm}$ ) are produced but flexirubin-type pigments are not produced (negative $\mathrm{KOH}$ test). Sodium and magnesium ions are essential for growth but calcium ions are not. The major cellular fatty acids of cells grown on TSA are iso- $\mathrm{C}_{15: 1}$, 
iso- $\mathrm{C}_{15: 0}$ and iso- $\mathrm{C}_{15: 0}$ 3-OH. MK-6 is the major respiratory quinone. The type species is Fulvibacter tottoriensis.

\section{Description of Fulvibacter tottoriensis sp. nov.}

Fulvibacter tottoriensis (tot.to.ri.en'sis. N.L. masc. adj. tottoriensis pertaining to Tottori, from where the type strain was isolated).

Displays the following properties in addition to those given in the genus description. Cells are $0.5-0.7 \mu \mathrm{m}$ wide and 5$14 \mu \mathrm{m}$ long. Three-day-old colonies on HSMA are yellowish brown in colour, circular with entire edges and $1-2 \mathrm{~mm}$ in diameter. Growth occurs at $10-37{ }^{\circ} \mathrm{C}$ (optimally at $25-30{ }^{\circ} \mathrm{C}$ ) and at $\mathrm{pH} 6.0-10.0$ (optimally at $\mathrm{pH}$ 7.0-9.0). Growth is not observed at $4,40,42$ or $45{ }^{\circ} \mathrm{C}$ or at $\mathrm{pH}$ 5.0. Growth occurs in the presence of $1-5 \%(\mathrm{w} / \mathrm{v})$ $\mathrm{NaCl}$. Growth does not occur in the absence of $\mathrm{NaCl}$, or with more than $5 \%(\mathrm{w} / \mathrm{v}) \mathrm{NaCl}$. Casein, aesculin, gelatin, starch and Tweens 20, 40 and 80 are degraded. Agar, DNA, carrageenan, carboxymethylcellulose, cellulose (filter paper) and chitin are not degraded. Weakly positive for $\beta$-galactosidase. Negative for reduction of nitrate and nitrite, production of indole from tryptophan, acidification of glucose and for arginine dihydrolase and urease activities. Peptone, Casamino acids and glutamate are utilized as nitrogen sources but ammonium sulphate and sodium nitrate are not utilized. No utilization or oxidation of carbon sources occurs in GN2 MicroPlates or API 50 $\mathrm{CH}$ strips, but L-glutamic acid, pyruvic acid, peptone and yeast extract are utilized with a conventional method. Adonitol, D-arabinose, D-galactose, D-glucose, D-mannose, glycerol, L-aspartic acid, L-rhamnose, maltose, mesoerythritol, raffinose and sucrose are not utilized. The detailed fatty acid content is given in Table 2. The G+C content of the chromosomal DNA is $35 \mathrm{~mol} \%$.

The type strain, MTT $-39^{\mathrm{T}} \quad\left(=\mathrm{NBRC} 102624^{\mathrm{T}}=\mathrm{KCTC}\right.$ $22214^{\mathrm{T}}=$ CGMCC $1.7058^{\mathrm{T}}$ ), was isolated from sediment from Tottori on the coast of the Sea of Japan.

\section{Acknowledgements}

This work was supported by the New Energy and Industrial Technology Development Organization (NEDO grant no. 04000182-0). The authors would like to thank Mr Motoyuki Ohuchi for his technical assistance.

\section{References}

Alonso, C., Warnecke, F., Amann, R. \& Pernthaler, J. (2007). High local and global diversity of Flavobacteria in marine plankton. Environ Microbiol 9, 1253-1266.

Bernardet, J.-F. \& Nakagawa, Y. (2006). An introduction to the family Flavobacteriaceae. In The Prokaryotes: a Handbook on the Biology of Bacteria, 3rd edn, vol. 7, pp. 455-480. Edited by M. Dworkin, S. Falkow, E. Rosenberg, K.-H. Schleifer \& E. Stackebrandt. New York: Springer.
Bernardet, J.-F., Nakagawa, Y. \& Holmes, B. (2002). Proposed minimal standards for describing new taxa of the family Flavobacteriaceae and emended description of the family. Int J Syst Evol Microbiol 52, 1049-1070.

Bowman, J. P. (2006). The marine clade of the family Flavobacteriaceae: the genera Aequorivita, Arenibacter, Cellulophaga, Croceibacter, Formosa, Gelidibacter, Gillisia, Maribacter, Mesonia, Muricauda, Polaribacter, Psychroflexus, Psychroserpens, Robiginitalea, Salegentibacter, Tenacibaculum, Ulvibacter, Vitellibacter and Zobellia. In The Prokaryotes: a Handbook on the Biology of Bacteria, 3rd edn, vol. 7, pp. 677-694. Edited by M. Dworkin, S. Falkow, E. Rosenberg, K.-H. Schleifer \& E. Stackebrandt. New York: Springer.

Buck, J. D. (1982). Nonstaining ( $\mathrm{KOH})$ method for determination of Gram reactions of marine bacteria. Appl Environ Microbiol 44, 992-993.

Choi, D. H. \& Cho, B. C. (2006). Lutibacter litoralis gen. nov., sp. nov., a marine bacterium of the family Flavobacteriaceae isolated from tidal flat sediment. Int J Syst Evol Microbiol 56, 771-776.

Choi, D. H., Kim, Y.-G., Hwang, C. Y., Yi, H., Chun, J. \& Cho, B. C. (2006). Tenacibaculum litoreum sp. nov., isolated from tidal flat sediment. Int J Syst Evol Microbiol 56, 635-640.

Cottrell, M. T. \& Kirchman, D. L. (2000). Natural assemblages of marine proteobacteria and members of the Cytophaga-Flavobacter cluster consuming low- and high-molecular-weight dissolved organic matter. Appl Environ Microbiol 66, 1692-1697.

Cowan, S. T. \& Steel, K. J. (1993). Manual for the Identification of Medical Bacteria, 3rd edn. London: Cambridge University Press.

Fautz, E. \& Reichenbach, H. (1980). A simple test for flexirubin-type pigments. FEMS Microbiol Lett 8, 87-91.

Glöckner, F. O., Fuchs, B. M. \& Amann, R. (1999). Bacterioplankton compositions of lakes and oceans: a first comparison based on fluorescence in situ hybridization. Appl Environ Microbiol 65, 3721-3726.

Gosink, J. J., Woese, C. R. \& Staley, J. T. (1998). Polaribacter gen. nov., with three new species, $P$. irgensii sp. nov., $P$. franzmannii sp. nov. and $P$. filamentus sp. nov., gas vacuolate polar marine bacteria of the Cytophaga-Flavobacterium-Bacteroides group and reclassification of 'Flectobacillus glomeratu' as Polaribacter glomeratus comb. nov. Int $J$ Syst Evol Microbiol 48, 223-235.

Jung, S.-Y., Oh, T.-K. \& Yoon, J.-H. (2006). Tenacibaculum aestuarii sp. nov., isolated from tidal flat sediment in Korea. Int J Syst Evol Microbiol 56, 1577-1581.

Khan, S. T., Nakagawa, Y. \& Harayama, S. (2007). Sediminibacter furfurosus gen. nov., sp. nov. and Gilvibacter sediminis gen. nov., sp. nov., novel members of the family Flavobacteriaceae. Int J Syst Evol Microbiol 57, 265-269.

Lewin, R. A. \& Lounsbery, D. C. (1969). Isolation, cultivation and characterization of flexibacteria. J Gen Microbiol 58, 145-170.

Mesbah, M., Premachandran, U. \& Whitman, W. B. (1989). Precise measurement of the $\mathrm{G}+\mathrm{C}$ content of deoxyribonucleic acid by highperformance liquid chromatography. Int J Syst Bacteriol 39, 159-167.

Minamisawa, K. (1990). Division of rhizobitoxine-producing and hydrogen-uptake positive strains of Bradyrhizobium japonicum by nifDKE sequence divergence. Plant Cell Physiol 31, 81-89.

Nakagawa, Y. \& Yamasato, K. (1993). Phylogenetic diversity of the genus Cytophaga revealed by $16 \mathrm{~S}$ rRNA sequencing and menaquinone analysis. J Gen Microbiol 139, 1155-1161.

Nedashkovskaya, O. I., Kim, S. B., Lysenko, A. M., Kalinovskaya, N. I., Mikhailov, V. V., Kim, S. I. \& Bae, S. K. (2005). Polaribacter butkevichii sp. nov., a novel marine mesophilic bacterium of the family Flavobacteriaceae. Curr Microbiol 51, 408-412. 
Needleman, S. B. \& Wunsch, C. D. (1970). A general method applicable to the search for similarities in the amino acid sequence of two proteins. J Mol Biol 48, 443-453.

Perry, L. B. (1973). Gliding motility in some non-spreading flexibacteria. J Appl Bacteriol 36, 227-232.

Rüger, H.-J. \& Krambeck, H.-J. (1994). Evaluation of the BIOLOG substrate metabolism system for classification of marine bacteria. Syst Appl Microbiol 17, 281-288.

Sheu, S.-Y., Lin, K.-Y., Chou, J.-S., Chang, P.-S., Arun, A. B., Young, C.-C. \& Chen, W.-M. (2007). Tenacibaculum litopenaei sp. nov., isolated from a shrimp mariculture pond. Int J Syst Evol Microbiol 57, 1148-1153.

Smibert, R. M. \& Krieg, N. R. (1981). General characterization. In Manual of Methods for General Microbiology, pp. 409-443. Edited by P. Gerhardt, R. G. E. Murray, R. N. Costilow, E. W. Nester, W. A. Wood, N. R. Krieg \& G. B. Phillips. Washington, DC: American Society for Microbiology.
Sohn, J. H., Lee, J.-H., Yi, H., Chun, J., Bae, K. S., Ahn, T.-Y. \& Kim, S. J. (2004). Kordia algicida gen. nov., sp. nov., an algicidal bacterium from red tide. Int J Syst Evol Microbiol 54, 675-680.

Suzuki, M., Nakagawa, Y., Harayama, S. \& Yamamoto, S. (2001). Phylogenetic analysis and taxonomic study of marine cytophaga-like bacteria: proposal for Tenacibaculum gen. nov., with Tenacibaculum maritimum comb. nov. and Tenacibaculum ovolyticum comb. nov., and description of Tenacibaculum mesophilum sp. nov. and Tenacibaculum amylolyticum sp. nov. Int J Syst Evol Microbiol 51, 1639-1652.

Yoon, J.-H., Kang, S.-J. \& Oh, T.-K. (2005). Tenacibaculum lutimaris sp. nov., isolated from a tidal flat in the Yellow Sea, Korea. Int J Syst Evol Microbiol 55, 793-798.

Yoon, J.-H., Kang, S.-J. \& Oh, T.-K. (2006). Tenacibaculum dokdonensis sp. nov., isolated from seawater. Int J Syst Evol Microbiol 56, $1251-1255$. 